|| ISSN(online): 2589-8698 || ISSN(print): 2589-868X ||

International Journal of Medical and Biomedical Studies

Available Online at www.ijmbs.info

NLM (National Library of Medicine ID: 101738825)

Index Copernicus Value 2019: 79.34

Original Research Article

Volume 5, Issue 8; August: 2021; Page No. 250-252

\title{
STUDY OF SERUM LIPID PROFILE IN BETA-THALASSEMIA MAJOR PATIENTS
}

\section{Dr. Sandeep Kulhari ${ }^{1}$, Dr Deepak Choudhary ${ }^{2}$}

${ }^{1,2}$ MBBS, MD (Paeditrics) Pandit Deendayal Upadhyaya Medical College, Churu.

Article Info: Received 21 June 2021; Accepted 09 August 2021

DOI: https://doi.org/10.32553/ijmbs.v5i8.2126

Corresponding author: Dr. Sandeep Kulhari

Conflict of interest: No conflict of interest.

\begin{abstract}
Background: Beta-thalassemia is the commonest single-gene disorder in the Indian population. Beta thalassemia major is caused by complete absence of beta globin chain production resulting from reduced synthesis of one or more globin chains which can be caused by different globin gene mutation resulting in ineffective hematopoiesis, increased hemolysis and early onset anemia.
\end{abstract}

Methods: A cross-sectional; case control study was done on 50 diagnosed Cases of beta-thalassemia major in the age group of 1 year to 18 years receiving regular blood transfusions; not suffering from any ailment or any other disease leading to deranged lipid profile were included. In controls; 50 normal healthy children were included.

Results: Lipid analyses of controls and thalassemic children. It is clear from the results that beta thalassemia major patients had significantly lower total cholesterol (TC), high-density lipoprotein cholesterol (HDL) and low-density lipoprsotein cholesterol (LDL) compared with controls $(\mathrm{p}<0.001)$.

Conclusion: Lipid profile in Beta thalassmia patients show significantly low levels of total cholesterol, LDLC and HDL-C. Keywords: Beta Thalassemia Major, Lipid Profile, Hypocholesterolemia.

\section{Introduction}

Beta-thalassemia is the commonest single-gene disorder in the Indian population. Beta thalassemia major is caused by complete absence of beta globin chain production resulting from reduced synthesis of one or more globin chains which can be caused by different globin gene mutation resulting in ineffective hematopoiesis, increased hemolysis and early onset anemia. Ten percent of the total worlds thalassemic are born in India every year. Certain communities in India, like Sindhis, Guajarati's, Punjabis, and Bengalis, are more commonly affected with beta thalassemia, the incidence varying from 1 to $17 \% .^{1-2}$

It has been estimated that the prevalence of pathological haemoglobinopathies in India is 1.2/1,000 live births, and with approximately 27 million births per year this would suggest the annual birth of 32,400 babies with a serious hemoglobin disorder. Reportedly, there are about 240 million carriers of $\beta$-thalassemia worldwide, i.e. $1.5 \%$ of world population. A WHO update on betathalassemia in India indicated a similar overall carrier frequency of 3-4\%, based on that the current national population would translate to between 35.6 and 47.5 million carriers of the disorder nationwide. The mainstay of treatment of thalassemia is regular blood (Packed Red Blood Cells) transfusions. The major complications of blood transfusion are those related to transmission of infectious agents or development of iron overload. ${ }^{3-4}$

\section{Materials and Methods}

A cross-sectional; case control study was done on 50 diagnosed Cases of beta-thalassemia major in the age group of 1 year to 18 years receiving regular blood transfusions; not suffering from any ailment or any other disease leading to deranged lipid profile were included. In controls; 50 normal healthy children were included. After explaining about purpose of study, outcome and explaining that respondent can refuse and withdraw from study at any time in local language an informed consent was taken. All details were recorded in a pre-tested pro-forma which included personal information, transfusion history, clinical examination and lipid profile of the patients. Lipid profiles were done using auto analyzer. Statistical analyses were performed by using IBM SPSS Statistics 22 .

\section{Results}


Table 1: Socio-demographic profile

\begin{tabular}{|l|l|l|}
\hline Socio-demographic variable & Case & Control \\
\hline Mean age \pm SD & $7.42 \pm 4.16$ years & $8.10 \pm 4.06$ years \\
\hline Male $:$ Female & $31: 19$ & $29: 21$ \\
\hline
\end{tabular}

Out of total 50 cases, 31 were female and 19 were male while out of total 50 controls 29 were female and 21 were male. Mean age of cases was $7.42 \pm 4.16$ years and of controls was $8.10 \pm 4.06$ years.

Table 2: Comparison of various parameters of lipid profile in cases and control group

\begin{tabular}{|l|l|l|l|}
\hline Lipid profile & Case & Control & p-value \\
\hline Total Cholesterol & $112.34 \pm 26.24$ & $124.25 \pm 14.54$ & $<0.001$ \\
\hline Triglyceride & $111.34 \pm 51.24$ & $74.62 \pm 16.02$ & $<0.001$ \\
\hline HDL & $26.21 \pm 9.24$ & $47.42 \pm 4.25$ & $<0.001$ \\
\hline LDL & $62.24 \pm 21.22$ & $76.21 \pm 15.31$ & $<0.001$ \\
\hline
\end{tabular}

Lipid analyses of controls and thalassemic children. It is clear from the results that beta thalassemia major patients had significantly lower total cholesterol (TC), high-density lipoprotein cholesterol (HDL) and low-density lipoprotein cholesterol (LDL) compared with controls $(\mathrm{p}<0.001)$.

\section{Discussion}

In this study lipid profile in beta thalassemia children were evaluated \&compared it with a group of healthy children. In our study it was found that there is significant difference in between the values of cases and controls. It is seen that in beta thalassemia major Patient's serum levels of HDL, LDL and TC is low as compared to controls. In addition of that Triglyceride levels were substantially high. This appears because of many factors. Results of present study correlate well with previous study ${ }^{5-9}$.

Most studies explain the mechanism of alteration in lipid profile of cases. This alteration is likely due to diminished hepatic biosynthesis as of anemia and iron overload, while a reduced extra hepatic lipolytic activity could account for the rise in circulating TG. Iron-loading and the effects of repeated blood transfusions induce a hepatic acute-phase response, which could determine an LDL-class shift towards protein-rich, denser particles ${ }^{7,8}$

Some authors ${ }^{10-12}$ suggested that accelerated erythropoiesis and increased uptake of LDL by macrophages and histiocytes of the reticulo endothelial system are the main determinants of low plasma cholesterol levels in beta thalassemia major.

Factors such as iron overload (high ferritin level), liver injury, and hormonal disturbances affects lipids pattern among patients with major form of beta-thalassemia, while some researchers observed that the lipid profile in thalassemia major patients is not influenced by age, sex, liver injury, and hemoglobin or ferritin levels. The higher erythroid bone marrow activity with the enhanced cholesterol consumption could be the dominant mechanism implicated in the lipid abnormalities of thalassemia major patients. However other researchers did not find such differences.

\section{Conclusion}

Lipid profile in Beta thalassmia patients show significantly low levels of total cholesterol, LDLC and HDL-C.

\section{References}

1. Louis C.K. Low. Growth of children with beta thalassemia major. Indian J Pediatr 2005 Feb; 72:159- 160 .

2. Verma IC, Choudhry VP, Jain PK. Prevention of thalassemia: A necessity in India. Indian J Pediatr 1992; 59: 649-654.

3. Agarwal, S., A. Gupta, U. R. Gupta, S. Sarwai, S. Phadke, and S. S. Agarwal. "Prenatal diagnosis in beta-thalassemia: an Indian experience." Fetal diagnosis and therapy 18, no. 5 (2003): 328-332.

4. Modell, Bernadette, and Matthew Darlison. "Global Epidemiology of Haemoglobin Disorders and Derived Service Indicators." Bulletin of the World Health Organization 86.6 (2008): 480- 487. PMC. Web. 14 Dec. 2014.

5. Al-Quobaili, Faizeh A., and Imad E. AbouAsali. "Serum levels of lipids and lipoproteins in Syrian patients with betathalassemia major." Saudi medical journal 25, no. 7 (2004): 871-875.

6. Mansi, Kamal M., and Talal A. Aburjai. "Lipid Profile in Jordanian Children with B-thalassemia Major." International Journal of Hematology and Oncology 18 (2008): 93-98.

7. Patne, A. B., P. J. Hisalkar, and S. B. Gaikwad. "Lipid Abnormalities in Patients of Beta 
Thalassaemia Major. "IJPBS, vol(2),issue 2,AprilJune(2012);106-112

8. Arıca, Vefik, Seçil Arıca, CahitÖzer, and Murat Çevik. "Serum Lipid Values in Children with Beta Thalassemia Major." PediatTherapeut 2, no. 130 (2012): 2161- 0665.

9. Maioli, M., G. B. Cuccuru, P. Pranzetti, A. Pacifico, and G. M. Cherchi. "Plasma lipids and lipoproteins pattern in betathalassemia major." Actahaematologica 71, no. 2 (1984): 106-110.

10. Maioli, Mario, Silvestro Pettinato, Gian Mario Cherchi, DomenicoGiraudi, Adolfo Pacifico, Giuseppe Pupita, and Massimo GB Tidore. "Plasma lipids in betathalassemia minor." Atherosclerosis 75, no. 2 (1989): 245-248.

11. Maioli, Mario, Giovanni B. Vigna, Giancarlo Tonolo, PatriziaBrizzi, MilcoCiccarese, Paola Donegà, MargheritaMaioli, and Renato Fellin. "Plasma lipoprotein composition, apolipoprotein (a) concentration and isoforms in $\beta$-thalassemia." Atherosclerosis 131, no. 1 (1997): 127-133

12. Goldfarb AW, Rachmilewitz EA, Eisenberg S. Abnormal low and highdensity lipoproteins in homozygous beta-thalassaemia. $\mathrm{Br} \mathrm{J}$ Haematol. 1991;79:481-486. 